Check for updates

Cite this: RSC Adv., 2017, 7, 35169

\title{
Improved performance of immobilized lipase by interfacial activation on $\mathrm{Fe}_{3} \mathrm{O}_{4}$ aPVBC nanoparticles
}

\begin{abstract}
Zhiming Chen, (D)* Leilei Liu and Renchun Yang
An effective strategy for enhancement of catalytic activity and stability of immobilized lipase by interfacial activation on $\mathrm{Fe}_{3} \mathrm{O}_{4}$ (aPVBC ( $\mathrm{Fe}_{3} \mathrm{O}_{4}$ (apolyvinylbenzyl chloride) nanoparticles was developed, which involved the fabrication of core-shelled $\mathrm{Fe}_{3} \mathrm{O}_{4}$ ( $\mathrm{PVBC}$ nanoparticles via an emulsion polymerization process and the subsequent immobilization of lipase in phosphate buffer. Due to the magnetic nature of $\mathrm{Fe}_{3} \mathrm{O}_{4}$ cores and the presence of chloromethyl-functionalized polymer shells, the $\mathrm{Fe}_{3} \mathrm{O}_{4}$ @PVBC nanoparticles were employed as valid magnetic carriers for lipase immobilization. Bradford assays indicated that the loading amount of lipase on the $\mathrm{Fe}_{3} \mathrm{O}_{4}$ (aPVBC nanoparticles was calculated to be $162.5 \mathrm{mg}$ protein per $\mathrm{g}$ particles. The catalytic activity of the immobilized lipase retained about $99.6 \pm 3.3 \%$ of the free enzyme activity, which was attributed to interfacial activation of lipase by $\mathrm{Fe}_{3} \mathrm{O}_{4}$ @PVBC nanoparticles. Thermal and urea tolerance tests revealed that the immobilized lipase exhibited much better stabilities. Additionally, the immobilized lipase retained more than $69.8 \%$ of its initial activities after 10 times of reuse. It is believed that the results of the present investigation may provide a versatile approach for designing and fabricating biocatalysts with high activation and stability.
\end{abstract}

Received 21st May 2017

Accepted 10th July 2017

DOI: $10.1039 / \mathrm{c} 7 \mathrm{ra05723g}$

rsc.li/rsc-advances

The increasing knowledge of enzyme structures and mech-

\section{Introduction}

Enzymes have attracted much research interest due to their high effectiveness, specificity and mild reaction conditions. ${ }^{1-9}$ Lipases are ubiquitous enzymes with various biological activities, including high activities, chemo-, regio-, and stereoselectivities and are widely used in enantioselective hydrolysis and esterification, chiral resolution, synthesis of enantioenriched monomers and macromolecules for polymerization, and other enzymatic reactions. ${ }^{\mathbf{1 0 , 1 1}}$ However, the major drawbacks for their industrial applications are their poor chemical and thermal durability as well as difficulty in recovery and reuse of the enzyme. ${ }^{12-15}$ To lengthen performance of enzyme for practical applications, immobilization of lipase on various supports is considered to be an effective strategy to improve the handling, stability and recycling. ${ }^{16,17}$ Previous studies show that the immobilization will produce slight distortions in the enzymes structure and may alter the properties of the enzyme. $^{18,19}$ Due to the uncontrollable of the changes of proteins structure, the immobilization of lipase was usually associated with a decrease in enzyme activity or a worsening of other catalytic features. ${ }^{19-21}$ Therefore, the development of strategy for the fabrication of immobilized lipase with high activity and stability is of vital importance for the immobilization of lipase.

School of Biological and Chemical Engineering, Anhui Polytechnic University, Wuhu 241000, PR China.E-mail: zmchen@ahpu.edu.cn anism should enable more controlled immobilizations. As we all know that a "lid" composed of either one or two amphiphilic $\alpha$-helices covers the active site of lipase, blocking substrate access in the closed conformation. ${ }^{22-24}$ The side of the "lid" facing towards the active site is hydrophobic and the side facing away is hydrophilic. ${ }^{22}$ In general, increasing the hydrophobicity of the surface in the immediate area surrounding the active site, exposing a large hydrophobic area which can interact with the hydrophobic interface and the catalytic triad becomes accessible to the hydrophobic substrate. ${ }^{25-30}$ It is expected that hydrophobic carriers would provide more access of the substrate to the active site of the immobilized lipase.

Nowadays, $\mathrm{Fe}_{3} \mathrm{O}_{4}$ nanoparticles have been showing great potential applications in lipase immobilization due to their unique magnetic properties, ready availability, and environmentally friendly merits. ${ }^{31,32}$ Correspondingly, considerable attention has been paid to the fabrication of $\mathrm{Fe}_{3} \mathrm{O}_{4}$ nanocomposites to enhance the performance of immobilized lipase. ${ }^{33-40}$ But due to the complexity of the immobilization process and enzyme structure, most improvements in catalytic performance of the reported immobilization are not always really related to the production of a more active or selective enzyme molecule. ${ }^{18}$ Bearing this in mind, we fabricated chloromethyl-functionalized $\mathrm{Fe}_{3} \mathrm{O}_{4} @$ PVBC nanoparticles with a core-shell structure as magnetic carriers for lipase immobilization. The immobilization of lipase on the core-shell $\mathrm{Fe}_{3}$ $\mathrm{O}_{4} @$ PVBC nanoparticles was conducted and the catalytic 
performance of the immobilized lipase was then investigated by the hydrolysis of $p$-nitrophenyl palmitate (pNPP) in phosphate buffer. Hydrolytic activity tests reveal that the immobilized lipase retains about $99.6 \pm 3.3 \%$ of the free enzyme activity. It was found that thermal stability and urea tolerance of the immobilized lipase were strengthened. Additionally, the immobilized lipase retained more than $69.8 \%$ of its initial activities after 10 times reuse.

\section{Experimental}

\section{Materials}

Candida rugosa lipase (type VII), pNPP, $p$-nitrophenol (pNP), Coomassie Brilliant Blue G-250 and bovine serum albumin (BSA) protein were purchased from Sigma-Aldrich. Vinylbenzyl chloride (VBC) was purchased from J\&K Scientific Ltd. (China) and was purified by vacuum distillation. All other chemicals and reagents were purchased from Aladdin Chemical Co. Ltd. (Shanghai, China), and used without further purification. Deionized water was used throughout.

\section{Preparation of $\mathrm{Fe}_{3} \mathrm{O}_{4} @ P V B C$ nanoparticles}

The $\mathrm{Fe}_{3} \mathrm{O}_{4}$ nanoparticles were synthesized by a solvothermal treatment of $\mathrm{Fe}(\mathrm{acac})_{3}$ in the presence of oleic acid and oleylamine, as described previously. ${ }^{41}$ After that, the as-obtained $\mathrm{Fe}_{3} \mathrm{O}_{4}$ nanoparticles was mixed in $36 \mathrm{~mL}$ water with $0.5 \mathrm{~mL}$ dodecanol and $200 \mathrm{mg}$ sodium dodecyl sulfate (SDS), and was treated by ultrasound for $10 \mathrm{~min}$ with $650 \mathrm{~W}$ protected by icewater bath to obtain $\mathrm{Fe}_{3} \mathrm{O}_{4}$ emulsion. $0.5 \mathrm{~mL}$ VBC was dispersed in $24 \mathrm{~mL}$ solution contained $50 \mathrm{mg}$ SDS and $0.3 \mathrm{~mL}$ dodecanol by $30 \mathrm{~min}$ of ultrasonic bath to obtain the monomer emulsion. $\mathrm{Fe}_{3} \mathrm{O}_{4}$ emulsion, monomer emulsion and $20 \mathrm{mg}$ potassium persulfate were added to three-neck flask and stirred for $30 \mathrm{~min}$ at $400 \mathrm{rpm}$ in nitrogen atmosphere. Then the reactor was placed in $80{ }^{\circ} \mathrm{C}$ water bath for $24 \mathrm{~h}$ to obtain $\mathrm{Fe}_{3} \mathrm{O}_{4} @ P V B C$ nanoparticles suspension. Subsequently, the as-obtained $\mathrm{Fe}_{3^{-}}$ $\mathrm{O}_{4} @ P V B C$ nanoparticles were collected, washed with ethanol $(25 \%, v / v)$ and water several times, and dried in a vacuum oven at $30{ }^{\circ} \mathrm{C}$ for $8 \mathrm{~h}$.

\section{Immobilization of lipase}

$10 \mathrm{mg} \mathrm{Fe}_{3} \mathrm{O}_{4} @ P V B C$ nanoparticles were dispersed in $2 \mathrm{~mL}$ of $1 \mathrm{M}$ ammonium solution by sonication for $2 \mathrm{~min}$. Subsequently, the mixture was incubated at $30^{\circ} \mathrm{C}$ in a shaker operating at 120 times $\min ^{-1}$ for $4 \mathrm{~h}$. After the reaction, the $\mathrm{Fe}_{3} \mathrm{O}_{4} @$ @PVBC nanoparticles were washed 2 times with water, dispersed in 5 $\mathrm{mL}$ glutaraldehyde $(2 \% \mathrm{v} / \mathrm{v})$ by sonication for $2 \mathrm{~min}$, and incubated at $30^{\circ} \mathrm{C}$ in a shaker operating at 120 times $\min ^{-1}$ for $9 \mathrm{~h}$. Then the $\mathrm{Fe}_{3} \mathrm{O}_{4} @ P V B C$ nanoparticles were washed 2 times with phosphate buffer $(0.1 \mathrm{M}, \mathrm{pH} 7.5)$, and dispersed in $2 \mathrm{~mL}$ phosphate buffer $(0.1 \mathrm{M}, \mathrm{pH} 7.5)$ containing $0.2 \mathrm{mg}$ lipase for the bond with lipase covalently. The reaction was conducted at $30{ }^{\circ} \mathrm{C}$ for $2 \mathrm{~h}$. Ultimately, the immobilized lipase was recovered by magnetic separation, washed with $2 \mathrm{~mL}$ phosphate buffer (0.1 M, pH 7.5) to remove excess lipase, and stored at $4{ }^{\circ} \mathrm{C}$ until they were used for activity related tests. Using the same procedures, the loading amount tests were conducted in $4 \mathrm{~mL}$ phosphate buffer (0.1 M, pH 7.5) containing $2 \mathrm{mg}$ lipase. The loading of lipase on $\mathrm{Fe}_{3} \mathrm{O}_{4} @$ PVBC nanoparticles was analysed by the Bradford method using BSA as a standard. The amount of immobilized lipase was calculated by subtracting the amount of free lipase from the total amount of the lipase used for the immobilization.

\section{Lipase activity assay}

The enzymatic activities of free and immobilized lipase were assayed by the hydrolysis of pNPP in phosphate buffer $(0.1 \mathrm{M})$ following the method described previously. ${ }^{41}$ Thermal stabilities of free and immobilized lipase were studied by measuring the residual activities of the enzyme after incubation in phosphate buffer $(0.1 \mathrm{M}, \mathrm{pH} 7.5)$ at $50{ }^{\circ} \mathrm{C}$ for $0-10 \mathrm{~h}$. Urea tolerance of free and immobilized lipase were investigated by measuring the residual activities of the enzyme after incubation in $1 \mathrm{~mL}$ phosphate buffer (0.1 M, pH 7.5) contained 0-6 mmol urea at $40{ }^{\circ} \mathrm{C}$ for $1 \mathrm{~h}$. The reusability of the immobilized lipase was determined by hydrolysis of pNPP by the recovered immobilized lipase with magnetic separation and compared with the first running (activity defined as 100\%).

\section{Characterization}

The powder X-ray diffraction (XRD) pattern of the $\mathrm{Fe}_{3} \mathrm{O}_{4} @ P V B C$ nanoparticles was recorded on a Shimadzu XRD-6000 X-ray diffractometer. The morphologies of the samples were investigated by using a scanning electron microscopy (SEM) of Model S-4800 (Hitachi) and a transmission electron microscopy (TEM) of Model JEM-2010 (JEOL). X-ray photoelectron spectroscopy (XPS) analysis of the surface was studied by an ESCALAB 250Xi spectrometer (Thermo Scientific) equipped with an Al Ka X-ray radiation source. Water contact angles measurement was measured by contact angle measurement instrument (JCY-4, Shanghai Fangrui Instrument Co. Ltd.). Before measurements, a small amount of $\mathrm{Fe}_{3} \mathrm{O}_{4} @$ PVBC nanoparticles was pressed at $5 \mathrm{MPa}$ into a disc. Fourier transform infrared spectroscopy (FTIR) spectra were obtained on a Vectortm 22. The magnetic properties of the products were detected at $300 \mathrm{~K}$ using a superconducting quantum interference device (SQUID, Quantum Design MPMS3).

\section{Results and discussion}

As described in Fig. 1, $\mathrm{Fe}_{3} \mathrm{O}_{4} @$ PVBC nanoparticles were fabricated for lipase immobilization, which involves the preparation of magnetic $\mathrm{Fe}_{3} \mathrm{O}_{4}$ nanoparticles in a solvothermal process and the subsequent polymerization of $\mathrm{VBC}$ and $\mathrm{Fe}_{3} \mathrm{O}_{4}$ nanoparticles

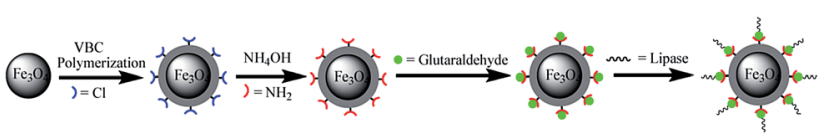

Fig. 1 Schematic representation the fabrication procedure of $\mathrm{Fe}_{3}-$ $\mathrm{O}_{4}$ aPVBC nanoparticles for lipase immobilization. 
in the solution containing dodecanol and sodium dodecyl sulphate. Fig. 2 shows typical XRD patterns of $\mathrm{Fe}_{3} \mathrm{O}_{4} @ P V B C$ nanoparticles and reveals that the product is assigned to $\mathrm{Fe}_{3} \mathrm{O}_{4}$ with a face-centered cubic (fcc) structure. All the positions of the peaks are in good agreement with values in the Joint Committee on Powder Diffraction Standards (JCPDS) card file no. 77-1545. Calculations with the Debye-Scherrer equation $(d=0.89 \lambda)$ $B \cos \theta)$ for the five strongest peaks $(220,311,400,511$, and 440) gave mean grain sizes of $14.9 \mathrm{~nm}$ for the $\mathrm{Fe}_{3} \mathrm{O}_{4} @ P V B C$ nanoparticles.

The typical SEM image of the as-synthesized products in Fig. 3a indicates that these magnetic nanocomposites exhibit an obvious spherical shape, and the diameters of the $\mathrm{Fe}_{3} \mathrm{O}_{4}$ @PVBC nanoparticles are 25-45 nm. In Fig. 3b the dark/light different contrast was clearly observed, suggesting a different phase composition, which indicated the formation of $\mathrm{Fe}_{3} \mathrm{O}_{4}$ @PVBC core-shell nanostructures. It is clearly seen that the $\mathrm{Fe}_{3} \mathrm{O}_{4}$ nanoparticles are completely encapsulated in a polymer shell and that there are no obvious voids between the core and the shell. The size of polymer shell is approximately 2-6 $\mathrm{nm}$. Selected-area electron diffraction (SAED) in Fig. 3c of the prepared $\mathrm{Fe}_{3} \mathrm{O}_{4}$ @PVBC nanoparticles further confirmed that they are fcc magnetite. More detailed structural information about the $\mathrm{Fe}_{3} \mathrm{O}_{4} @$ PVBC nanoparticles was obtained using a high resolution TEM (HRTEM). Fig. 3d shows that an amorphous polymer layers coating covered the $\mathrm{Fe}_{3} \mathrm{O}_{4}$ nanoparticles. The lattice fringe calculated from the HRTEM image was $0.30 \mathrm{~nm}$, fitting well with the (220) planes of fcc $\mathrm{Fe}_{3} \mathrm{O}_{4}$ structure.

The typical $\mathrm{C} 1 \mathrm{~s}, \mathrm{Cl} 2 \mathrm{p}$, and $\mathrm{Fe} 2 \mathrm{p}$ X-ray photoelectron spectroscopy (XPS) survey spectra of the $\mathrm{Fe}_{3} \mathrm{O}_{4} @ P V B C$ nanoparticles are depicted in Fig. 4a-c. The asymmetric C 1s peak was decomposed into two peaks at 284.6 and $285.9 \mathrm{eV}$, which were ascribed to $\mathrm{C}$ atoms in aromatic and aliphatic part of the PVBC. ${ }^{42,43}$ The $\mathrm{Cl} 2 \mathrm{p}$ peak consists of a spin-orbit split $\left(\mathrm{Cl} 2 \mathrm{p}_{3 / 2}\right.$ and $\mathrm{Cl} 2 \mathrm{p}_{1 / 2}$ ) doublet at the $\mathrm{BE}$ of 200.1 and $201.6 \mathrm{eV}$, and is attributed to the chlorine atom signals associated with $\mathrm{R}-\mathrm{Cl}$ groups. ${ }^{\mathbf{4 4 5}}$ The $\mathrm{Fe} 2 \mathrm{p}_{1 / 2}$ and $\mathrm{Fe} 2 \mathrm{p}_{3 / 2}$ peaks are found to be located at 723.9 and $710.7 \mathrm{eV}$. No Fe 2 p signals of $\gamma-\mathrm{Fe}_{2} \mathrm{O}_{3}$ can be clearly identified on the magnetic samples, indicating that the product is $\mathrm{Fe}_{3} \mathrm{O}_{4}$ rather than $\gamma-\mathrm{Fe}_{2} \mathrm{O}_{3}{ }^{46}$ Fig. $4 \mathrm{~d}$ shows the wettability of a water droplet on the surface of a $\mathrm{Fe}_{3} \mathrm{O}_{4} @ \mathrm{PVBC}$

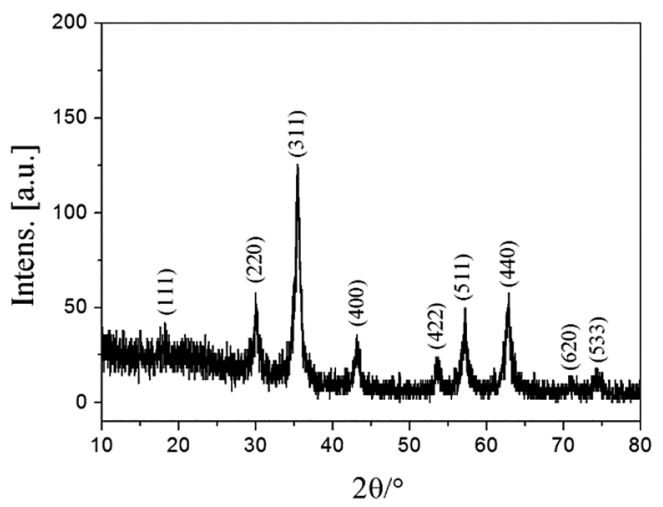

Fig. 2 XRD patterns of $\mathrm{Fe}_{3} \mathrm{O}_{4}$ @PVBC nanoparticles.
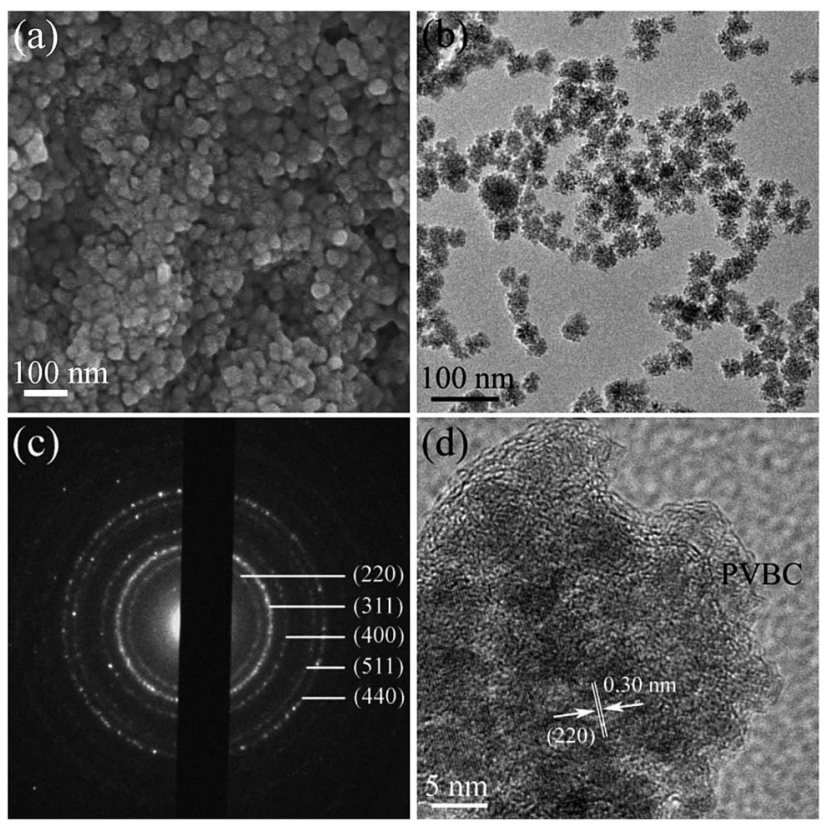

Fig. 3 (a) SEM and (b) TEM, (c) SAED and (d) HRTEM images of $\mathrm{Fe}_{3}-$ $\mathrm{O}_{4}$ @PVBC nanoparticles.

disc that was prepared by pressing $\mathrm{Fe}_{3} \mathrm{O}_{4} @ P V B C$ particles. The static contact angle of water is $135.5 \pm 2.0^{\circ}$, indicating that $\mathrm{Fe}_{3} \mathrm{O}_{4} @$ @PVC nanocomposites are hydrophobic in nature. The hydrophobic character has been further confirmed by observed the system of water and $\mathrm{Fe}_{3} \mathrm{O}_{4} @$ PVBC nanoparticles, which the magnetic nanocomposites are non-disperse in water. If $\mathrm{Fe}_{3}$ $\mathrm{O}_{4} @ P V B C$ nanoparticles were mixed with ammonia, the products were transformed to amino-functionalized polymer via an amination process and became dispersible in aqueous environments. It is observed that the $\mathrm{Fe}_{3} \mathrm{O}_{4}$ @PVBC nanoparticles are well dispersed in ammonia solution.
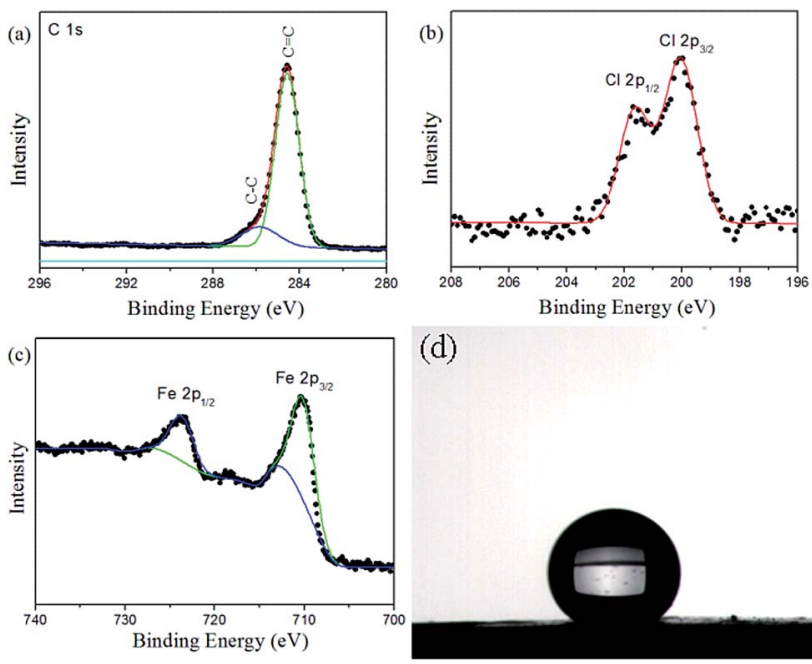

(d)

Fig. 4 (a) $\mathrm{C}$ 1s, (b) $\mathrm{Cl} 2 \mathrm{p}$ and (c) Fe 2p XPS spectra of $\mathrm{Fe}_{3} \mathrm{O}_{4}$ (aPVBC nanoparticles, and (d) image of a water droplet sitting on $\mathrm{Fe}_{3} \mathrm{O}_{4}(\mathrm{aPVBC}$ nanoparticles. 
The $-\mathrm{CH}_{2} \mathrm{Cl}$ functional groups of the $\mathrm{Fe}_{3} \mathrm{O}_{4}$ @PVBC nanoparticles was further determined by FT-IR analysis. The strong peak at $572 \mathrm{~cm}^{-1}$ corresponds to the characteristic band of $\mathrm{Fe}-$ O vibration. ${ }^{47}$ In Fig. 5a, apart from the peaks (2920, 2851, 1636, 1511, 1456, 1420, 1062 and $823 \mathrm{~cm}^{-1}$ ) corresponding to the benzene ring and methylene which result from the polymer shell, the vibration band at 1263 and $653 \mathrm{~cm}^{-1}$ were assigned to stretching vibrations of $\mathrm{CH}_{2}-\mathrm{Cl}^{48}$ All these results reveal that a large amount of $-\mathrm{CH}_{2} \mathrm{Cl}$ functional groups are bonded to the polymer shell in the $\mathrm{Fe}_{3} \mathrm{O}_{4} @$ PVBC nanoparticles, which made possible the amination of the nanoparticles. To confirm this hypothesis, the $\mathrm{Fe}_{3} \mathrm{O}_{4} @$ @VBC nanoparticles were incubated with ammonia solution. It is observed that the signals at 34103450 and $1627 \mathrm{~cm}^{-1}$ for $-\mathrm{NH}_{2}$ stretching vibration, and 1384 $\mathrm{cm}^{-1}$ for $\mathrm{C}-\mathrm{N}$ stretching vibration appeared (Fig. 5b), indicating that the $\mathrm{Fe}_{3} \mathrm{O}_{4} @$ PVBC nanoparticles were transformed into amino-functionalized polymer. ${ }^{49}$

Magnetic measurements of the $\mathrm{Fe}_{3} \mathrm{O}_{4} @ P V B C$ nanoparticles were investigated by a SQUID magnetometer at $300 \mathrm{~K}$ with an applied magnetic field ranging from -40 to $40 \mathrm{kOe}$. As illustrated in Fig. 6, the isothermal magnetization of $\mathrm{Fe}_{3} \mathrm{O}_{4} @ P V B C$ samples showed a rapid increase with increasing applied magnetic field. The saturation magnetization, remanent magnetization and coercivity are $46.8 \mathrm{emu} \mathrm{g}^{-1}, 2.6 \mathrm{emu} \mathrm{g}^{-1}$, and 31.2 Oe, respectively. The partially enlarged curves demonstrate that the $\mathrm{Fe}_{3} \mathrm{O}_{4} @$ @PBC sample has the ferromagnetic behaviour (the down inset of Fig. 6). The magnetic separability of the $\mathrm{Fe}_{3} \mathrm{O}_{4} @ P V B C$ nanoparticles was tested in $1 \mathrm{M}$ ammonia solution by placing a magnet near the glass bottle (the up inset of Fig. 6). The dark brown particles were attracted toward the magnet within $20 \mathrm{~s}$, demonstrating directly that the $\mathrm{Fe}_{3} \mathrm{O}_{4}$ @PVBC nanoparticles possess magnetic properties. This will provide an easy and efficient way to separate $\mathrm{Fe}_{3} \mathrm{O}_{4} @$ @PBC nanoparticles from a suspension system.

To prove the application of $\mathrm{Fe}_{3} \mathrm{O}_{4} @$ PVBC nanoparticles in biotechnology, the products were used as supports for lipase immobilization. As described in Fig. 1, the magnetic polymer functionalized with aldehyde group were achieved and used to bond with lipase covalently. According the Bradford method, the loading amount of lipase on the $\mathrm{Fe}_{3} \mathrm{O}_{4}$ @PVBC nanoparticles

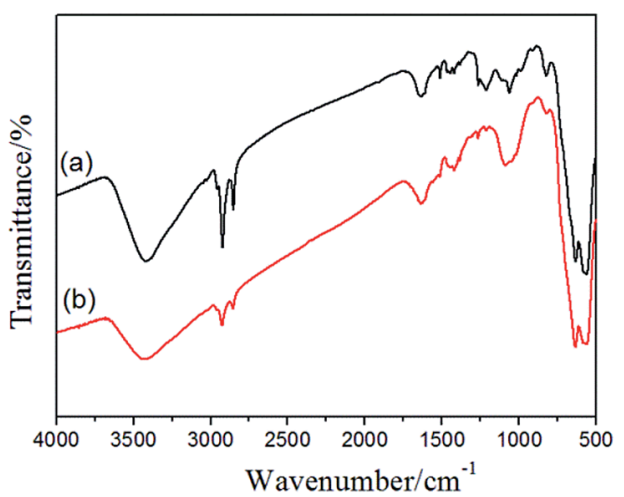

Fig. 5 FT-IR spectra of (a) $\mathrm{Fe}_{3} \mathrm{O}_{4}$ (aPVBC and (b) the amino-functionalized $\mathrm{Fe}_{3} \mathrm{O}_{4} @ \mathrm{PV} V \mathrm{BC}$ nanoparticles.

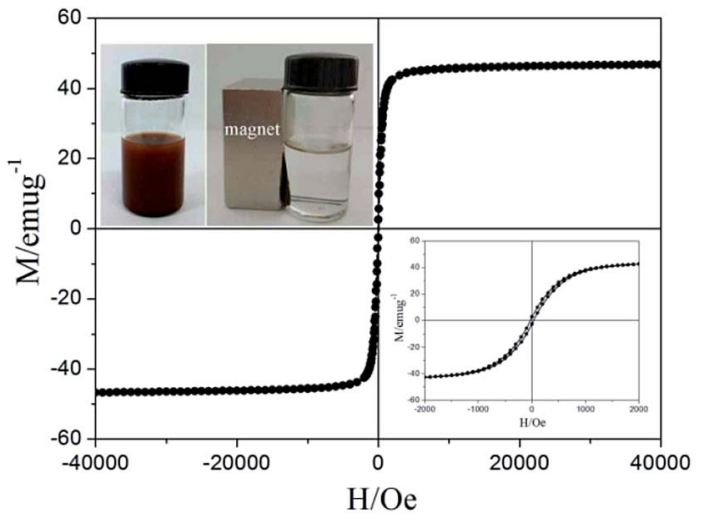

Fig. 6 Magnetic hysteresis loops and enlarged view (the down inset) of $\mathrm{Fe}_{3} \mathrm{O}_{4} \mathrm{QPVBC}$ nanoparticles at $300 \mathrm{~K}$, and the up insets: $\mathrm{Fe}_{3} \mathrm{O}_{4} \mathrm{Q}$ PVBC nanoparticles suspended in $1 \mathrm{M}$ ammonia solution (left) and separated from the solution under an external magnetic field (right).

was calculated to be $162.5 \mathrm{mg}$ protein per $\mathrm{g}$ particles. The high lipase loading amount might be attributed to the existence of abundant $-\mathrm{CH}_{2} \mathrm{Cl}$ on $\mathrm{Fe}_{3} \mathrm{O}_{4}$ @PVBC supports for the attachment of enzymes. The catalytic activities of free and immobilized lipase were determined by measuring the initial hydrolysis rate of pNPP. By taking the maximum activity value of the immobilized and free lipase under optimal conditions as $100 \%$, the activities obtained from other conditions were expressed as relative activities. Hydrolytic activity tests reveal that the maximum activities of the immobilized and free lipase were both at pH 7.5 and $40{ }^{\circ} \mathrm{C}$. However, hydrolytic activity tests reveal that the immobilized lipase retains about $99.6 \pm 3.3 \%$ of the free enzyme activity. The high catalytic activity remaining after immobilization may be attributed to interfacial activation of lipase by $\mathrm{Fe}_{3} \mathrm{O}_{4}$ @PVBC nanoparticles, which is similar to the hyperactivation of lipase adsorbed on hydrophobic materials in previous reported literatures. ${ }^{25-27}$ The hydrophobic interface could provide a better micro-aqueous environment for lipase molecules, a better dispersion support to avoid agglomeration, and flexibility in opening of the $\alpha$-helix lid to achieve active catalytic sites which tends to offer a better improvement in enzyme activity. ${ }^{50}$

For practical applications, it is usually required that biocatalysts possess high stabilities and keep catalytic activity in relatively tough environmental conditions. Therefore, the thermal stabilities and denaturation of the free and immobilized lipase were studied. Fig. 7a shows the comparison of thermal stabilities of free and immobilized lipase at $50{ }^{\circ} \mathrm{C}$ in phosphate buffer (0.1 M, pH 7.5). The residual activity of both free and immobilized lipase exhibited a similar trend, whereas the immobilized lipase decreased less and more slowly than the free one. The free lipase lost about $69 \%$ of its initial activity after $10 \mathrm{~h}$ of incubation, but the immobilized lipase could retain about $60 \%$ of its activity after this period of time. These results demonstrated that the thermal stability of immobilized lipase was much better than the free one, which could be explained by the formation of covalent bonds between the lipase molecules and the magnetic carriers enhancing the enzyme rigidity, 

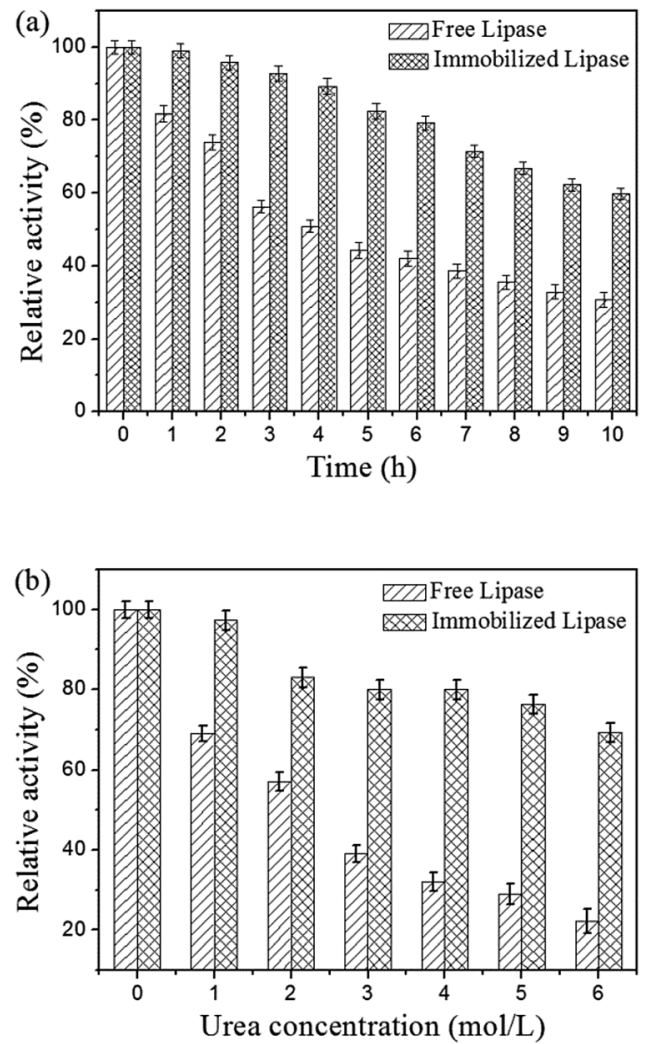

Fig. 7 (a) Thermal stabilities of free and immobilized lipase at $50{ }^{\circ} \mathrm{C}$ and (b) effect of urea concentration on the activity of free and immobilized lipase.

protected it from unfolding and prevented the conformation transition of the enzyme at high temperature. ${ }^{38,39}$ Fig. $7 \mathrm{~b}$ illustrates the comparison of urea tolerance of free and immobilized lipase. It is observed that the lipase remained protected against the urea denaturation after immobilization. The immobilized lipase exhibited strong urea tolerance to retain $69.3 \%$ of the residual activity in the presence of $6 \mathrm{M}$ urea, while the free one only retained approximately $22.2 \%$ of the residual activity in $6 \mathrm{M}$ urea. The possible explanation of the urea tolerance of lipase could be that the active sites of the enzyme molecules become less accessible for the urea molecules after covalent attached onto the magnetic carriers. ${ }^{51}$ The free and immobilized lipase were stored at $4{ }^{\circ} \mathrm{C}$ in phosphate buffer $(0.1 \mathrm{M}, \mathrm{pH}$ 7.5) and measured for a period of 14 days. The free lipase lost about $19 \%$ of its initial activity within 14 days, while the residual activity of immobilized lipase could retain about $88 \%$ of its activity after this period of time. These results demonstrated that storage stability of the immobilized lipase was enhanced.

Reusability is the most important advantage of the immobilized lipase compared to the free lipase. To evaluate the reusability, the immobilized lipase was washed with phosphate buffer (0.1 M, pH 7.5) after one catalysis run and reintroduced into a fresh pNPP solution for another hydrolysis at $40{ }^{\circ} \mathrm{C}$. As shown in Fig. 8, the immobilized lipase shows good stability and retains more than $69.8 \%$ of its initial activity after 10 consecutive reuses. This result confirmed that the immobilized

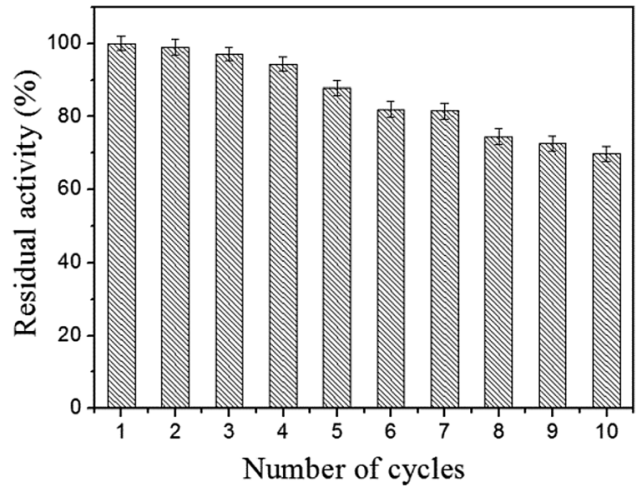

Fig. 8 Reusability of the immobilized lipase.

lipase on $\mathrm{Fe}_{3} \mathrm{O}_{4} @ P V B C$ nanoparticles has a good durability and magnetic recovery. The decrease of activity is ascribed to the denaturation of the immobilized lipase molecules and the leakage of immobilized enzyme upon the recovery process.

\section{Conclusions}

In summary, we reported an effective strategy for enhancement of catalytic activity and stability of immobilized lipase by interfacial activation on $\mathrm{Fe}_{3} \mathrm{O}_{4} @ P V B C$ nanoparticles. The $\mathrm{Fe}_{3}$ $\mathrm{O}_{4} @ P V B C$ nanoparticles were functionalized with $-\mathrm{CH}_{2} \mathrm{Cl}$ groups, which provides the potential application in lipase immobilization. Bradford assays indicated that the lipase loading amount on $\mathrm{Fe}_{3} \mathrm{O}_{4}$ @PVBC nanoparticles was $162.5 \mathrm{mg}$ protein per $\mathrm{g}$. The relative activity of the immobilized lipase reaches up to $99.6 \pm 3.3 \%$ compared with the free one, which is attributed to the enhanced interfacial activity of lipase due to the interaction between lipase and the surface of $\mathrm{Fe}_{3} \mathrm{O}_{4} @ P V B C$ nanoparticles. Hydrolytic activity tests indicate that the immobilized lipase exhibited much better thermal stability and urea tolerance. Additionally, the immobilized lipase retained more than $69.8 \%$ of its initial activities after 10 times reuse. The combination of interfacial activation, improved stability and easy recovery of magnetic $\mathrm{Fe}_{3} \mathrm{O}_{4} @ \mathrm{PVBC}$ nanoparticles presents an attractive process for lipase immobilization and provides a promising catalyst for practical applications.

\section{Acknowledgements}

This work is supported by the National Natural Science Foundation of China (21471002 and 51572004), the Outstanding Youth Science Foundation of Anhui Polytechnic University (2015JQ01) and the Young and Middle-Aged Talent Program of Anhui Polytechnic University (2016BJRC001).

\section{Notes and references}

1 M. Held, A. Schmid, J. B. van Beilen and B. Witholt, Pure Appl. Chem., 2000, 72, 1337-1343.

2 J. Y. Song, P. Su, Y. Yang, T. Wang and Y. Yang, J. Mater. Chem. B, 2016, 4, 5873-5882. 
3 J. J. Sun, R. Yendluri, K. Liu, Y. Guo, Y. Lvov and X. H. Yan, Phys. Chem. Chem. Phys., 2017, 19, 562-567.

4 C. Zhang, X. R. Wang, M. Hou, X. Y. Li, X. L. Wu and J. Ge, ACS Appl. Mater. Interfaces, 2017, 9, 13831-13836.

5 Z. X. Li, Y. Ding, S. M. Li, Y. B. Jiang, Z. Liu and J. Ge, Nanoscale, 2016, 8, 17440-17445.

6 X. L. Wu, C. Yang, J. Ge and Z. Liu, Nanoscale, 2015, 7, 1888318886.

7 X. L. Wu, M. Hou and J. Ge, Catal. Sci. Technol., 2015, 5, 5077-5085.

8 X. L. Wu, J. Ge, C. Yang, M. Hou and Z. Liu, Chem. Commun., 2015, 51, 13408-13411.

9 J. Ge, J. D. Lei and R. N. Zare, Nano Lett., 2011, 11, 2551-2554.

10 M. Kalantari, M. Kazemeini, F. Tabandeh and A. Arpanaei, J. Mater. Chem., 2012, 22, 8385-8393.

11 C. H. Lee, T. S. Lin and C. Y. Mou, Nano Today, 2009, 4, 165179.

12 R. A. Sheldon and S. van Pelt, Chem. Soc. Rev., 2013, 42, 6223-6235.

13 E. T. Hwang and M. B. Gu, Eng. Life Sci., 2013, 13, 49-61.

14 E. Yilmaz, M. Sezgin and M. Yilmaz, J. Mol. Catal. B: Enzym., 2011, 69, 35-41.

15 X. H. Li, H. Zhu, J. Feng, J. W. Zhang, X. Deng, B. F. Zhou, H. L. Zhang, D. S. Xue, F. S. Li, N. J. Mellors, Y. F. Li and Y. Peng, Carbon, 2013, 60, 488-497.

16 Y. Kuwahara, T. Yamanishi, T. Kamegawa, K. Mori and H. Yamashita, ChemCatChem, 2013, 5, 2527-2536.

17 Y. Kuwahara, T. Yamanishi, T. Kamegawa, K. Mori, M. Che and H. Yamashita, Chem. Commun., 2012, 48, 2882-2884.

18 R. C. Rodrigues, C. Ortiz, Á. Berenguer-Murcia, R. Torres and R. Fernández-Lafuente, Chem. Soc. Rev., 2013, 42, 6290-6307.

19 U. Hanefeld, L. Gardossi and E. Magner, Chem. Soc. Rev., 2009, 38, 453-468.

20 G. Fernández-Lafuente, J. M. Palomo, C. Mateo, R. Munilla, C. Ortiz, Z. Cabrera, J. M. Guisán and R. Fernández-Lafuente, Biomacromolecules, 2006, 7, 2610-2615.

21 J. C. S. dos Santos, O. Barbosa, C. Ortiz, A. Berenguer-Murcia, R. C. Rodrigues and R. Fernandez-Lafuente, ChemCatChem, 2015, 7, 2413-2432.

22 A. R. M. Yahya, W. A. Anderson and M. Moo-Young, Enzyme Microb. Technol., 1998, 23, 438-450.

23 A. Bastida, P. Sabuquillo, P. Armisen, R. FernándezLafuente, J. Huguet and J. M. Guisán, Biotechnol. Bioeng., 1998, 58, 486-493.

24 M. T. Reetz, Adv. Mater., 1997, 9, 943-954.

25 I. Mahmood, I. Ahmad, G. Chen and L. Huizhou, Biochem. Eng. J., 2013, 73, 72-79.

26 K. Solanki and M. N. Gupta, New J. Chem., 2011, 35, 25512556.

27 K. C. Badgujar and B. M. Bhanage, Ind. Eng. Chem. Res., 2014, 53, 18806-18815.
28 J. Mukherjee and M. N. Gupta, Bioresour. Technol., 2016, 209, 166-171.

29 W. W. Zhang, X. L. Yang, J. Q. Jia, N. Wang, C. L. Hu and X. Q. Yu, J. Mol. Catal. B: Enzym., 2015, 115, 83-89.

30 V. Patel, C. Shah, M. Deshpande and D. Madamwar, Appl. Biochem. Biotechnol., 2016, 178, 1630-1651.

31 Y. J. Cui, Y. F. Li, Y. Yang, X. Liu, L. Lei, L. C. Zhou and F. Pan, J. Biotechnol., 2010, 150, 171-174.

32 X. Wang, P. P. Dou, P. Zhao, C. M. Zhao, Y. Ding and P. Xu, ChemSusChem, 2009, 2, 947-950.

33 M. Hartmann and D. Jung, J. Mater. Chem., 2010, 20, 844857.

34 M. C. R. Franssen, P. Steunenberg, E. L. Scott, H. Zuilhof and J. P. M. Sanders, Chem. Soc. Rev., 2013, 42, 6491-6533.

35 Y. J. Li, G. W. Zhou, W. T. Qiao and Y. Y. Wang, Mater. Sci. Eng., B, 2009, 162, 120-126.

36 W. Z. Shen, L. W. Ren, H. Zhou, S. C. Zhang and W. B. Fan, J. Mater. Chem., 2011, 21, 3890-3894.

37 M. Y. Chang and R. S. Juang, Enzyme Microb. Technol., 2005, 36, 75-82.

38 Y. Yong, Y. X. Bai, Y. F. Li, L. Lin, Y. J. Cui and C. G. Xia, Process Biochem., 2008, 43, 1179-1185.

39 H. Zhu, C. Hou, Y. J. Li, G. H. Zhao, X. Liu, K. Hou and Y. F. Li, Chem.-Asian J., 2013, 8, 1447-1454.

40 X. Liu, X. Chen, Y. F. Li, X. Y. Wang, X. M. Peng and W. W. Zhu, ACS Appl. Mater. Interfaces, 2012, 4, 5169-5178.

41 Z. M. Chen, L. L. Liu, X. D. Wu and R. C. Yang, RSC Adv., 2016, 6, 108583-108589.

42 H. H. Jiang, X. Y. Han, Z. L. Li, X. C. Chen, Y. H. Hou, L. G. Gai, D. C. Li, X. R. Lu and T. L. Fu, Colloids Surf., A, 2012, 401, 74-80.

43 D. E. Weibel, F. Kessler and G. V. d. S. Mota, Polym. Chem., 2010, 1, 645-649.

44 G. L. Li, D. L. Zeng, L. Wang, B. Y. Zong, K. G. Neoh and E. T. Kang, Macromolecules, 2009, 42, 8561-8565.

45 D. Tastet, M. Save, F. Charrier, B. Charrier, J. B. Ledeuil, J. C. Dupin and L. Billon, Polymer, 2011, 52, 606-616.

46 Y. Tian, B. B. Yu, X. Li and K. Li, J. Mater. Chem., 2011, 21, 2476-2481.

47 J. Hong, D. M. Xu, P. J. Gong, H. J. Ma, L. Dong and S. D. Yao, J. Chromatogr. B: Anal. Technol. Biomed. Life Sci., 2007, 850, 499-506.

48 W. T. Lu, Z. G. Shao, G. Zhang, Y. Zhao and B. L. Yi, J. Power Sources, 2014, 248, 905-914.

49 Z. M. Chen, W. H. Xu, L. Jin, J. J. Zha, T. X. Tao, Y. Lin and Z. Wang, J. Mater. Chem. A, 2014, 2, 18339-18344.

50 K. C. Badgujar and B. M. Bhanage, Bioprocess Biosyst. Eng., 2017, 40, 741-757.

51 S. Rauf, A. Ihsan, K. Akhtar, M. A. Ghauri, M. Rahman, M. A. Anwar and A. M. Khalid, J. Biotechnol., 2006, 121, 351-360. 